\title{
Advances in Water Quality Monitoring and Assessment in Marine and Coastal Regions
}

\author{
Alessandro Bergamasco $^{1, *(\mathbb{D})}$, Hong Quan Nguyen $^{2}(\mathbb{D})$, Gabriella Caruso ${ }^{3}\left(\mathbb{D}\right.$, Qianguo Xing $^{4,5}$ \\ and Eleonora Carol ${ }^{6}$ (D)
}

check for

updates

Citation: Bergamasco, A.; Nguyen H.Q.; Caruso, G.; Xing, Q.; Carol, E. Advances in Water Quality

Monitoring and Assessment in Marine and Coastal Regions. Water 2021, 13, 1926. https://doi.org/ $10.3390 /$ w13141926

Received: 5 July 2021

Accepted: 8 July 2021

Published: 13 July 2021

Publisher's Note: MDPI stays neutral with regard to jurisdictional claims in published maps and institutional affiliations.

Copyright: (c) 2021 by the authors. Licensee MDPI, Basel, Switzerland. This article is an open access article distributed under the terms and conditions of the Creative Commons Attribution (CC BY) license (https:// creativecommons.org/licenses/by/ $4.0 /)$.
1 Institute of Marine Sciences (CNR-ISMAR), Italian National Research Council, 30122 Venice, Italy

2 Center of Water Management and Climate Change, Institute for Environment and Resources, Vietnam National University, Ho Chi Minh City 70000, Vietnam; nhquan@wacc.edu.vn

3 Institute of Polar Sciences (CNR-ISP), Italian National Research Council, Spianata S. Raineri, 98122 Messina, Italy; gabriella.caruso@cnr.it

4 CAS Key Laboratory of Coastal Environmental Processes and Ecological Remediation, Yantai Institute of Coastal Zone Research (YIC), Chinese Academy of Sciences (CAS), Yantai 264003, China; qgxing@yic.ac.cn 5 Center for Ocean Mega-Science, Chinese Academy of Sciences, Qingdao 266071, China

6 Consejo Nacional de Investigaciones Cientificas y Tecnicas (CONICET), La Plata, Buenos Aires B1900, Argentina; eleocarol@fcnym.unlp.edu.ar

* Correspondence: alessandro.bergamasco@ve.ismar.cnr.it

Coastal environments include several different habitat typologies, from shorelines to estuaries, and rocky and muddy environments. All these ecosystems are very vulnerable to anthropogenic pressures, climate fluctuations, stressing the need to monitor their quality status and suggest possible measures for the remediation and recovery of their natural equilibria.

In the light of these considerations, this Special Issue (SI) collects a number of multi-faceted scientific contributions on the quality of aquatic ecosystems, with a particular focus on the transitional environments where marine and terrestrial habitats are in close relationship.

A multidisciplinary approach including updated knowledge of coastal oceanography, hydrogeology, biogeochemistry and marine ecology has been promoted to discuss issues spanning from the assessment of quality status to the strategies for preventing eutrophication phenomena.

Results from field studies encompassing innovative technologies (e.g., automatic systems, fixed points of observation, remote sensing), promising approaches and methodologies (e.g., indicators, microbiology, structural and functional changes of biodiversity, link between quality and climate-related local changes) and modeling are reported here, dealing with surface waters in coastal regions. The papers in this Special Issue can be grouped according to the following topics:

- Microbial variables as indirect estimators of ecosystem quality: Microbial variables can provide useful insights to assess the quality of marine and coastal ecosystems. Thanks to their ability and metabolic plasticity, microbial communities including both autotrophic and heterotrophic components can modify their structure and metabolism to adapt to or cope with changing environmental conditions; this ability has been recognized by previous studies [1-3]. In this context, one example of the use of microbial variables as a tool for the classification of the ecological status of marine ecosystems is suggested by Decembrini et al. [4]. In this study, a suite of microbial abundance and activity data were linked to trophic patterns in a coastal Mediterranean area, where different levels of phytoplankton-bacteria association were observed in coastal, intermediate and off-shore waters. This allowed a conceptual model of an ecosystem functioning during the late spring period to be built, which could be exported to 
characterize the status of other aquatic ecosystems. Additionally, the intestinal microbiota of marine organisms, such as fishes, is responsive to environmental stressors in terms of its composition and functional metabolism, suggesting its potential use as an indirect tool to monitor environmental changes. Floris et al. [5] have documented, in a multi-disciplinary approach based on the study of the intestinal microbial ecology and metal chemistry of the fillets of wild grey mullets, that they reflect the variability of a Western Mediterranean coastal lagoon, proving to be a good approach for studying such complex ecosystems, characterized by a notable variability in environmental factors due to anthropogenic and natural stressors.

- Advanced systems for monitoring algal blooms, dissolved oxygen and water anoxia: The water quality monitoring systems and approaches are becoming more flexible with various purposes, e.g., water constituents, algal blooms, dissolved oxygen and water anoxia. On the basis of in situ data measured by chemical sensors, Liu et al. [6] explored the spatio-temporal changes in dissolved oxygen as well as the forming mechanisms in the coastal waters of Hong Kong, China. Using satellite images, Gao et al. [7] revealed a decreasing trend in the phytoplankton biomass of the coastal Pearl River estuary plume over the period from 1998-2018 which is supposed to be induced by the decreasing nutrient input of the river runoff and the weakening of wind-forced mixing. Liu et al. [8] evaluated the changes in the suspended sediments caused by the sand excavating activities and successfully assessed the potential effects on the construction of Hong Kong-Zhuhai-Macau Bridge. Wang et al. [9] demonstrated the capabilities of satellite images with different spatial resolutions in estimating the coverages of marine floating macroalgae blooms. On the basis of UAV or in situ hyperspectral data, Gai et al. [10] proposed an improved model for retrieving Chlorophyll-a concentration, Jiang et al. [11] evaluated the performances of different empirical and machine-learning models in monitoring the concentrations of Chlorophyll-a and suspended sediments, and Xue et al. [12] tested a latest CNN approach in estimating Chlorophyll-a concentration.

- Continental sea water mixing in coastal zones and its role in modifying marine, lagoonal and terrestrial habitats: One of the most widespread and worrying phenomena affecting coastal areas is the progressive salinization of water resources and vadose zone, both from natural and anthropogenic processes. Practices such as groundwater pumping and drainage canals for land reclamation can cause problems related to sea water intrusion and soil salinization in agricultural areas. In this sense, in Lovrinović et al.'s study [13], the results of the implementation of real-time monitoring systems of the dynamics and electrical conductivity of groundwater in two coastal aquifers are presented; one of them located in the Neretva valley in southeastern Croatia and the other located south of the Venetian lagoon in northeastern Italy. Using time series analysis, the authors show the influence that sea level oscillations exert on groundwater electrical conductivity and on the piezometric head values. Likewise, they observe that the precipitation rate is detected as a driving mechanism of groundwater parameters in shallow geological units. In Zancanaro et al. [14], three years' worth of monitoring results in an experimental agricultural field located on the southern margin of the Venice Lagoon are presented, where the matrix potential of the soil, the water quality of the soil pores and groundwater, and the physical and chemical properties of the soil were monitored at five stations. The study confirmed that the experimental site was strongly affected by soil and water salinity, and two main pollution processes were identified. The first of them was mainly driven by seawater intrusion from the nearby lagoon and salty water courses, while the second one resulted from interactions between the peaty soil and salts that were originally in the place. The results of these studies will be of great help in future management and planning of potential solutions for the mitigation of salt contamination in high-value coastal farmlands. 
- Modeling: Water quality modeling has been considered a cost-effective tool to understand the process and impact of various (e.g., anthropogenic) factors on water quality and to provide information for mitigating water pollution $[15,16]$. Water quality modeling involves diverse processes leading to numerous model parameters and variables which are presented in different mathematical forms. They are basically classified into two main categories. The first one is a stochastic model where model inputs, parameters or variables do not have fixed values at a particular point in space and time (e.g., Bayesian statistical model, artificial neural network) and sometimes include uncertainty estimation [17-19]. The second type is the deterministic model which does not, or only indirectly, considers the randomness and comes along with hydrodynamic processes $[18,20]$. Mathematical models have been applied in a wide range of water bodies systems, e.g., lake, river, estuary, sea, and to various parameters, e.g., dissolved oxygen, nutrients, heavy metals, pathogens [20,21]. In the SI, Jiang B. et al. [11] and Xue Y. et al. [12] have successfully demonstrated two applications of stochastic modeling in prediction of Chlorophyll- $a$ and Total Suspended Particulate [11] and Chlorophyll- $a$ [12]. The convolutional neural network (CNN) and back-propagation neural network (BPNN) in data-driven machine learning models are very advanced in water quality modeling. Both of these applications have become popular given the increasing attention in extending water quality monitoring networks to be used for water quality early warning system [22]. However, in its nature, stochastic modeling considers quality processes as a black box. It is hard to interpret the cause-effect mechanism as in the deterministic models. Lorenz et al. [23], presented the application of multivariate approaches, including trend analysis, cluster analysis, and principal component analysis to understand the trend and causes of water pollution in Thi Vai river estuary, Southern Vietnam. Thus, combining both the stochastic and deterministic approaches is highly recommended. In addition, in the marine and coastal regions, it is highly important to link catchment/river quality to estuary and coastal/sea water bodies (including global scale and multiple pollutants) in order to effectively control water quality in the areas [16,21].

- Sensitivity of aquatic ecosystems to impact of anthropogenic origin: It is acknowledged that emerging contaminants such as personal care products, cosmetics and sunscreens can cause ecotoxicological threats. Astel et al. [24] assess for the first time the presence of selected organic UV filters in core sediments of four Polish beaches exposed to heavy touristic pressure that is likely to increase due to climatic shifts. Management actions such as a water diversion project conceived to improve water quality can trigger unexpected consequences: changes in nutrient dynamics were found to occur in an urban lake, sustaining the bloom of the cyanobacterium Microcystis [25].

The Editors hope that this SI could serve as an invaluable reference for coastal zone managers and practitioners.

Conflicts of Interest: The authors declare no conflict of interest.

\section{References}

1. Caruso, G.; Azzaro, M.; Caroppo, C.; Decembrini, F.; Monticelli, L.S.; Leonardi, M.; Maimone, G.; Zaccone, R.; La Ferla, R. Microbial community and its potential as descriptor of environmental status. ICES J. Mar. Sci. 2016, 73, 2174-2177. [CrossRef]

2. Caruso, G.; La Ferla, R.; Azzaro, M.; Zoppini, A.; Marino, G.; Petochi, T.; Corinaldesi, C.; Leonardi, M.; Zaccone, R.; Fonda Umani, S. Microbial assemblages for environmental quality assessment: Knowledge, gaps and usefulness in the European Marine Strategy Framework Directive. Crit. Rev. Microbiol. 2016, 42, 883-904. [CrossRef] [PubMed]

3. Caruso, G.; Leonardi, M.; Monticelli, L.; Decembrini, F.; Azzaro, F.; Crisafi, E.; Zappalà, G.; Bergamasco, A.; Vizzini, S. Assessment of the ecological status of transitional waters in Sicily (Italy): First characterisation and classification according to a multiparametric approach. Mar. Pollut. Bull. 2010, 60, 1682-1690. [CrossRef] [PubMed]

4. Decembrini, F.; Caroppo, C.; Caruso, G.; Bergamasco, A. Linking Microbial Functioning and Trophic Pathways to Ecological Status in a Coastal Mediterranean Ecosystem. Water 2021, 13, 1325. [CrossRef] 
5. Floris, R.; Sanna, G.; Satta, C.T.; Piga, C.; Sanna, F.; Lugliè, A.; Fois, N. Intestinal Microbial Ecology and Fillet Metal Chemistry of Wild Grey Mullets Reflect the Variability of the Aquatic Environment in a Western Mediterranean Coastal Lagoon (Santa Giusta, Sardinia, Italy). Water 2021, 13, 879. [CrossRef]

6. Liu, G.; He, W.; Cai, S. Seasonal variation of dissolved oxygen in the Southeast of the Pearl River Estuary. Water 2020, $12,2475$. [CrossRef]

7. Gao, N.; Ma, Y.; Zhao, M.; Zhang, L.; Zhan, H.; Cai, S.; He, Q. Quantile analysis of long-term trends of near-surface chlorophyll-a in the Pearl River plume. Water 2020, 12, 1662. [CrossRef]

8. Liu, F.; Zhang, T.; Ye, H.; Tang, S. Using Satellite Remote Sensing to Study the Effect of Sand Excavation on the Suspended Sediment in the Hong Kong-Zhuhai-Macau Bridge Region. Water 2021, 13, 435. [CrossRef]

9. Wang, X.; Xing, Q.; An, D.; Meng, L.; Zheng, X.; Jiang, B.; Liu, H. Effects of Spatial Resolution on the SatelliteObservation of Floating Macroalgae Blooms. Water 2021, 13, 1761. [CrossRef]

10. Gai, Y.; Yu, D.; Zhou, Y.; Yang, L.; Chen, C.; Chen, J. An improved model for chlorophyll-a concentration retrieval in coastal waters based on UAV-Borne hyperspectral imagery: A case study in Qingdao, China. Water 2020, 12, 2769. [CrossRef]

11. Jiang, B.; Liu, H.; Xing, Q.; Cai, J.; Zheng, X.; Li, L.; Liu, S.; Zheng, Z.; Xu, H.; Meng, L. Evaluating traditional empirical models and BPNN models in monitoring the concentrations of chlorophyll-A and total suspended particulate of eutrophic and turbid waters. Water 2021, 13, 650. [CrossRef]

12. Xue, Y.; Zhu, L.; Zou, B.; Wen, Y.-M.; Long, Y.-H.; Zhou, S.-L. Research on Inversion Mechanism of Chlorophyll-A Concentration in Water Bodies Using a Convolutional Neural Network Model. Water 2021, 13, 664. [CrossRef]

13. Lovrinović, I.; Bergamasco, A.; Srzić, V.; Cavallina, C.; Holjević, D.; Donnici, S.; Erceg, J.; Zaggia, L.; Tosi, L. Groundwater Monitoring Systems to Understand Sea Water Intrusion Dynamics in the Mediterranean: The Neretva Valley and the Southern Venice Coastal Aquifers Case Studies. Water 2021, 13, 561. [CrossRef]

14. Zancanaro, E.; Teatini, P.; Scudiero, E.; Morari, F. Identification of the Origins of Vadose-Zone Salinity on an Agricultural Site in the Venice Coastland by Ionic Molar Ratio Analysis. Water 2020, 12, 3363. [CrossRef]

15. Chapra, S.C. Surface Water-Quality Modeling; Waveland Press: Long Grove, IL, USA, 2008.

16. Tang, T.; Strokal, M.; van Vliet, M.T.; Seuntjens, P.; Burek, P.; Kroeze, C.; Langan, S.; Wada, Y. Bridging global, basin and local-scale water quality modeling towards enhancing water quality management worldwide. Curr. Opin. Environ. Sustain. 2019, 36, 39-48. [CrossRef]

17. Cox, B. A review of currently available in-stream water-quality models and their applicability for simulating dissolved oxygen in lowland rivers. Sci. Total Environ. 2003, 314, 335-377. [CrossRef]

18. Nguyen, H.-Q. Modeling of Nutrient Dynamics during Flood Events at Catchment Scale in Tropical Regions. Ph.D. Thesis, Universität Braunschweig, Braunschweig, Germany, 2010.

19. Novotny, V.; Olem, H. Modeling and monitoring diffuse pollution. In Water Quality: Prevention, Identification, and Management of Diffuse Pollution; Van Nostrand Reinhold: New York, NY, USA, 1994; pp. 507-571.

20. Ji, Z.-G. Hydrodynamics and Water Quality: Modeling Rivers, Lakes, and Estuaries; John Wiley \& Sons: Hoboken, NJ, USA, 2017.

21. Strokal, M.; Spanier, J.E.; Kroeze, C.; Koelmans, A.A.; Flörke, M.; Franssen, W.; Hofstra, N.; Langan, S.; Tang, T.; van Vliet, M.T. Global multi-pollutant modelling of water quality: Scientific challenges and future directions. Curr. Opin. Environ. Sustain. 2019, 36, 116-125. [CrossRef]

22. Tiyasha; Tung, T.M.; Yaseen, Z.M. A survey on river water quality modelling using artificial intelligence models: 2000-2020. J. Hydrol. 2020, 585, 124670. [CrossRef]

23. Lorenz, M.; Nguyen, H.Q.; Le, T.D.H.; Zeunert, S.; Dang, D.H.; Le, Q.D.; Le, H.; Meon, G. Discovering Water Quality Changes and Patterns of the Endangered Thi Vai Estuary in Southern Vietnam through Trend and Multivariate Analysis. Water 2021, 13, 1330. [CrossRef]

24. Astel, A.; Stec, M.; Rykowska, I. Occurrence and Distribution of UV Filters in Beach Sediments of the Southern Baltic Sea Coast. Water 2020, 12, 3024. [CrossRef]

25. Chen, X.; Bai, D.; Song, C.; Zhou, Y.; Cao, X. Microcystis Bloom in an Urban Lake after River Water Diversion-A Case Study. Water 2020, 12, 1811. [CrossRef] 